\title{
EVALUASI DOKUMEN WAJIB SERTIFIKASI SNI ISO 9001:2015 di UMKM BATIK SEMARANG 16
}

\section{Evaluation of Documents Mandatory for SNI ISO 9001:2015 Certification in UMKM Batik Semarang 16}

\author{
Prasetyo Utomo, Bambang Purwanggono, Arfan Bakhtiar \\ Departemen Teknik Industri, Fakultas Teknik, Universitas Diponegoro, \\ JI. Prof. Soedarto, SH, Kampus Undip Tembalang, Semarang, Indonesia 50275 \\ Email: prasetyyoutomo@gmail.com
}

\begin{abstract}
Abstrak
Batik Indonesia mempunyai potensi ekspor berdaya saing di pasar internasional serta mengembangkan pasar di dalam negeri. Untuk dapat memiliki daya saing dan kepuasan di pasar nasional atau internasional, UMKM Batik di Indonesia harus memiliki keunggulan kompetitif produk melalui sistem manajemen mutu, sehingga dapat meningkatkan mutu produk yang dihasilkan. Sistem manajemen mutu saat ini dikembangkan dalam sertifikasi ISO 9001. Penelitian ini dilakukan di UMKM Batik Semarang 16 dimana produk yang dihasilkan, yaitu batik cap dan batik tulis. Namun, terjadi keluhan dari pelanggan akan produk yang dihasilkan tidak sesuai dengan standar yang telah disetujui dan kualitas produk yang diproduksi belum stabil atau konstan sehingga terjadi perbedaan kualitas hasil produksi tiap produk. Oleh karena itu, Batik Semarang 16 berkeinginan untuk memiliki sertifikat ISO 9001:2015. Penelitian ini bertujuan untuk mengevaluasi kondisi UMKM Batik Semarang 16 saat ini dan seberapa besar kesiapan UMKM Batik Semarang 16 untuk sertifikasi ISO 9001:2015. Metode yang digunakan pada penelitian ini adalah Gap Analysis dimana metode tersebut bertujuan untuk mengevaluasi keadaan UMKM saat ini dan menilai kesiapan UMKM untuk sertifikasi ISO 9001:2015. Perhitungan Gap Analysis menggunakan checklist berdasarkan klausul dari ISO 9001:2015. Hasil dari perhitungan tersebut menunjukkan seberapa besar kesiapan UMKM Batik Semarang 16 untuk melakukan sertifikasi ISO 9001:2015.
\end{abstract}

Kata Kunci: batik, gap analysis, iso 9001:2015, sistem manajemen mutu

\begin{abstract}
Indonesian batik has competitive export potential in the international market as well as developing a domestic market. To be able to have competitiveness and satisfaction in national or international markets, SMEs Batik in Indonesia must have a competitive advantage of products through a quality management system, to improve the quality of the products produced. The current quality management system was developed in ISO 9001 certification. The research was carried out at UMKM Batik Semarang 16 where the products produced were stamped and written batik. However, complaints from customers about the products produced are not under the agreed standards and the quality of the products produced are not stable or constant, resulting in differences in the quality of the production of each product. Therefore, UMKM Batik Semarang 16 wishes to have an ISO 9001: 2015 certificate. This study aims to evaluate the current condition of UMKM Batik Semarang 16 and how much preparedness UMKM Batik Semarang 16 is for ISO 9001: 2015 certification. The method used in this research is Gap Analysis where the method aims to evaluate the current state of UMKM and assess the readiness of UMKM for ISO 9001: 2015 certification. Gap Analysis calculations use a checklist based on clauses of ISO 9001: 2015. The results of these calculations indicate how much the readiness of UMKM Batik Semarang 16 to conduct ISO 9001: 2015 certification.
\end{abstract}

Keywords: batik, gap analysis, ISO 9001:2015, quality management system

\section{PENDAHULUAN}

Batik merupakan salah satu warisan bangsa Indonesia yang perlu dijaga dan dilestarikan keberadaannya, terlebih lagi batik telah diangkat sebagai pakaian nasional yang mempunyai ciri khas dan menunjukkan identitas bangsa, sering dikenakan oleh pejabat pemerintahan maupun masyarakat luas dalam berbagai acara resmi serta mengandung filsafat yang mendalam yang memberikan ajaran kebaikan. Berdasarkan data Kementerian Perindustrian, nilai ekspor batik tahun 2015 sebesar USD 156 juta naik sebesar 10 persen dari tahun 2014. Ini menunjukkan batik Indonesia mempunyai potensi ekspor berdaya saing di pasar internasional serta mengembangkan pasar di dalam negeri. Untuk dapat memiliki daya saing dan kepuasan di pasar nasional atau internasional, UMKM Batik di Indonesia harus memiliki keunggulan kompetitif produk melalui 
sistem manajemen mutu, sehingga dapat meningkatkan mutu produk yang dihasilkan.

Sistem manajemen mutu banyak dikembangkan dalam sertifikasi standar ISO 9001. Standar ISO 9001 adalah suatu standar yang berisi persyaratan terkait sistem manajemen mutu yang diterbitkan oleh International Organization for Standardization (Tukiran, 2016). Adapun tujuan dari ISO 9001 adalah membantu perusahaan-perusahaan untuk mengimplementasikan dan menjalankan sistem manajemen mutu yang efektif dengan meningkatkan kemampuan perusahaan untuk mendesain, memproduksi, dan mengirimkan produk dan jasa yang berkualitas (Fernando, Purwanggono \& Wicaksono, 2017). Menurut Jang dan Lin pada Psomas \& Kafetzopoulos, (2014), pengimplementasian ISO 9001 memberikan dampak positif secara langsung pada kinerja operasional. Pada perspektif pelanggan, pengimplementasian ISO 9001 menciptakan sentimen positif dari pelanggan dan mendorong pelanggan untuk memberikan dukungan jangka panjang serta meningkatkan kepuasan dan loyalitas dari pelanggan. Selain itu, ISO 9001 juga meningkatkan kualitas produk yang dihasilkan sehingga dapat mengurangi biaya akibat kegagalan atau kualitas produk yang tidak memenuhi standar yang ditetapkan (Boiral, 2012).

Batik Semarang 16 merupakan UMKM yang bergerak dalam bidang produksi batik, meliputi batik cap dan batik tulis. Saat ini, Batik Semarang 16 tidak hanya memasarkan produknya di dalam negeri, tetapi juga melakukan ekspor ke beberapa negara di Eropa, seperti Portugal, Belanda, Spanyol, Jerman, dan lain-lain. Namun, terdapat beberapa keluhan dari pelanggan akan produk yang dihasilkan tidak sesuai dengan standar yang telah disetujui. Selain itu, kualitas produk yang diproduksi belum stabil atau konstan sehingga terjadi perbedaan kualitas hasil produksi tiap produk. Hal ini merupakan salah satu dampak tidak langsung dari tidak adanya sertifikasi ISO dimana dengan adanya sertifikasi ISO, menandakan sistem manajemen mutu dari perusahaan tersebut telah teraudit dan telah dijalankan. Oleh karena itu, Batik Semarang 16 berkeinginan untuk memiliki sertifikat ISO 9001:2015 agar dapat meningkatkan jaminan kualitas produk, meningkatkan kepuasan pelanggan, dan meningkatkan citra perusahaan di publik sehingga meningkatkan kepercayaan dari konsumen, meningkatkan akses pasar, serta memiliki daya saing dengan produk lain di pasar domestik maupun internasional. Menurut Zaramdini dalam Psomas, Fotopoulos dan Kafetzopoulos (2010), keuntungan yang didapat dari pengimplementasian standar ISO 9001:2015 adalah peningkatan jaminan kualitas produk dan jasa, peningkatan efisiensi biaya, peningkatan produktivitas organisasi, serta meningkatkan citra perusahaan di publik.

Penelitian ini bertujuan untuk menganalisis kesiapan UMKM Batik Semarang 16 dalam melakukan sertifikasi standar ISO 9001:2015 dan membantu dalam hal penyusunan dokumen yang dibutuhkan. Metode yang digunakan dalam penelitian ini adalah metode gap analysis dimana metode tersebut digunakan untuk menganalisa kondisi perusahaan saat ini dan membandingkannya dengan kondisi seharusnya yang dicapai untuk mencapai ISO 9001:2015. Hasil yang didapat dari gap analysis berupa perbandingan antara sistem yang sudah ada dengan sistem yang dibutuhkan sehingga dapat diketahui kekurangan dari sistem yang ada untuk dilakukan perbaikan

\section{TINJAUAN PUSTAKA}

\section{a. Sistem Manajemen Mutu}

Menurut Gaspersz dalam Simanjuntak dan Suawa (2014) mendefinisikan Sistem Manajemen Mutu sebagai sekumpulan prosedur terdokumentasi dan praktek-praktek standar untuk manajemen sistem yang bertujuan menjamin kesesuaian dari suatu proses dan produk terhadap kebutuhan atau persyaratan tertentu. Kebutuhan atau persyaratan itu ditentukan atau dispesifikasikan oleh pelanggan dan organisasi. Sistem Manajemen Mutu mendefinisikan bagaimana organisasi menerapkan praktek-praktek manajemen mutu secara konsisten untuk memenuhi kebutuhan pelanggan dan pasar.

Banyak manfaat yang dapat diperoleh dari penerapan Sistem Manajemen Mutu, khususnya bagi pelanggan, perusahaan, maupun bagi staf dan karyawan. Manfaat tersebut didasarkan pada sistem kerja dari Manajemen Mutu yang berlandaskan pada kepuasan pelanggan dan perbaikan berkesinambungan (continuous improvement). $\mathrm{Hal}$ ini akan mengurangi berbagai bentuk pemborosan dan meningkatkan kepuasan pelanggan. Kedua faktor tersebut pada akhirnya akan meningkatkan keuntungan (Simanjuntak dan Suawa, 2014).

\section{b. ISO 9001:2015}

Standar ISO adalah suatu standar yang berisi persyaratan terkait sistem manajemen 
mutu yang diterbitkan oleh IOS (International Organization for Standarization). Standar ISO 9001 merupakan standar persyaratan manajemen dan bukan merupakan standar spesifikasi produk. Sebagai standar persyaratan manajemen, isi dari ISO 9001 merupakan serangkaian pasal-pasal persyaratan yang menjamin konsistensi dari proses manajemen terkait dengan mutu dalam suatu sistem (Psomas, 2014). Pasal-pasal pada ISO 9001 berisi apa saja yang harus dilakukan bagi organisasi yang hendak mengimplementasikan dan membangun sistem manajemen organisasinya masingmasing sehingga terbangun suatu sistem manajemen yang menjelaskan bagaimana cara melakukan rangkaian kegiatan yang menjadi persyaratan secara spesifik pada organisasinya masing-masing (Fernando dkk, 2017).

ISO 9001 menjelaskan syarat-syarat dasar untuk sebuah sistem manajemen mutu (Manders, 2015). Setiap lima tahun IOS, sebagai induk organisasi yang bertanggung jawab terhadap harmonisasi standar yang berlaku di dunia melakukan review secara rutin atas standar ISO uang telah diterbitkan. Dalam situs resmi ISO, penerapan Sistem Manajemen Mutu ISO 9001 ini sukses digunakan di seluruh dunia. Pada tahun 2013, lebih dari satu juta perusahaan dari 187 negara di dunia melakukan sertifikasi ISO 9001, namun tidak sedikit perusahaan dan organisasi lain yang menggunakan standar ini tanpa memiliki sertifikat (Badan Standardiasai Nasional, 2015).

\section{c. Gap Analysis}

Gap analysis didefinisikan oleh IT Infrastructure Library (ITIL) sebagai aktivitas yang membandingkan dua macam data dan mengidentifikasikan perbedaannya. Gap analysis biasa digunakan untuk membandingkan suatu set persyaratan, umumnya terstruktur pada suatu set area, topic atau kategori, sehingga membuat gap analysis menjadi efektif karena checklist yang dibuat terstruktur dan sesuai dengan topiknya.

Berikut merupakan langkah-langkah dalam melakukan gap analysis:

\section{- Penentuan score}

Score yang digunakan pada gap analysis ditunjukkan pada tabel 1 sebagai berikut (Fernando dkk, 2017):
Tabel 1 Score gap analysis

\begin{tabular}{ll}
\hline Score & Pengertian \\
\hline 1 & $\begin{array}{l}\text { Jika organisasi tidak memahami apa } \\
\text { yang diperlukan dan tidak } \\
\text { melakukan hal tersebut }\end{array}$ \\
\hline 2 & $\begin{array}{l}\text { Jika organisasi memahami } \\
\text { pentingnya aktivitas tersebut namun } \\
\text { tidak melakukannya }\end{array}$ \\
\hline 3 & $\begin{array}{l}\text { Jika organisasi memiliki dokumen } \\
\text { namun belum diterapkan atau } \\
\text { dilakukan tetapi tidak dicatat }\end{array}$ \\
\hline 4 & $\begin{array}{l}\text { Jika organisasi melakukan aktivitas } \\
\text { tetapi tidak konsisten }\end{array}$ \\
\hline 5 & $\begin{array}{l}\text { Jika organisasi melakukan aktivitas } \\
\text { dengan baik (dilakukan secara } \\
\text { konsisten) }\end{array}$ \\
\hline
\end{tabular}

(Sumber : Prakarsa, 2015)

- Penilaian checklist

Penilaian checklist oleh responden berdasarkan kondisi organisasi saat ini. Responden yang dipilih adalah responden yang memiliki kompetensi di bidangnya (Fernando dkk, 2017). Penilaian yang dilakukan berdasarkan ketentuan scoring yang dijelaskan pada tabel 2.3 diatas.

\section{- Penilaian gap}

Penilaian gap bertujuan untuk melihat seberapa besar gap yang ada pada perusahaan. Nilai persentase diperoleh dengan menjumlahkan score per variabel dan membaginya dengan nilai maksimal pada variabel tersebut. Semakin kecil gap yang ada, maka akan semakin baik. Untuk mengukur kesiapan nilai persentase yang dihasilkan menunjukkan kesiapan perusahaan dalam pengimplementasian ISO 9001:2015 (Fernando dkk, 2017). Tabel 2 menunjukkan range dari nilai gap sebagai berikut:

Tabel 2 Range persentase

\begin{tabular}{|c|c|c|}
\hline $\begin{array}{l}\text { Kate } \\
\text { gori }\end{array}$ & Persentase & Uraian \\
\hline 1 & $75 \%-100 \%$ & $\begin{array}{l}\text { Organisasi siap untuk } \\
\text { melengkapi QMS ISO } \\
9001: 2015 \text { dan } \\
\text { melakukan sertifikasi }\end{array}$ \\
\hline 2 & $50 \%-74 \%$ & $\begin{array}{l}\text { Organisasi masih } \\
\text { harus memperbaik } \\
\text { QMS untuk persiapan } \\
\text { ISO 9001:2015 }\end{array}$ \\
\hline 3 & $1 \%-49 \%$ & $\begin{array}{lr}\text { SMM suatu organisas } \\
\text { sangat } & \text { butuh } \\
\text { perbaikan } & \text { karena } \\
\text { berbeda jauh dar } \\
\text { Sistem } & \text { Manajemen } \\
\text { Kualitas } & \text { ISO } \\
9001: 2015 & \end{array}$ \\
\hline
\end{tabular}

(Sumber : Prakarsa, 2015) 


\section{d. Fault Tree Analysis}

Fault Tree Analysis merupakan analisis yang digunakan untuk menentukan akar penyebab potensi kegagalan yang terjadi dalam sistem sehingga dilakukan upaya untuk mengurangi produk cacat tersebut (Foster, 2004). Fault Tree Analysis berorientasi pada fungsi (function oriented) atau lebih dikenal dengan "top down" approach karena analisa ini berawal dari system level (top) dan meneruskannya ke bawah. Titik awal dari analisa ini adalah pengidentifikasian mode kegagalan fungsional pada top level dari suatu sistem atau subsistem.

\section{METODE PENELITIAN}

Metode yang digunakan dalam penelitian ini adalah metode gap analysis. Gap analysis dilakukan dengan membandingkan keadaan saat ini dengan keadaan yang seharusnya dicapai untuk mencapai ISO 9001:2015. Perbandingan yang dinilai adalah dokumendokumen sistem kualitas yang telah dibuat oleh perusahaan. Dokumen yang akan digunakan didapat dari hasil wawancara dengan beberapa manajer dengan menggunakan checklist audit internal ISO 9001:2015 dan pengamatan langsung di UMKM Batik Semarang 16. Hasil yang didapat akan dibobotkan skor 1-5 dengan persentasinya masing-masing dan dibuat range kesiapan perusahaan dalam pengimplementasiannya. Range tersebut didapatkan dari diskusi dengan para ahli. Data yang diperoleh akan digunakan untuk mengevaluasi gap apa saja yang ada di dalam pengimplementasian ISO 9001:2015. Gap-gap yang ada akan tentukan prioritas perbaikan berdasarkan persentasi yang paling kecil. Setelah mengetahui gap yang ada, dilakukan analisis menggunakan metode fault tree analysis untuk mengetahui akar permasalahan yang terjadi sehingga didapatkan usulan perbaikan berdasarkan analisis yang telah dibuat.

\section{a. Alur Penelitian}

Alur penelitian berisi tahapan penelitian yang harus ditetapkan terlebih dahulu sebelum melakukan pemeacahan masalah dengan tujuan agar penelitian dapat dilakukan dengan terarah, terencana, sistematis, dan memudahkan dalam menganalisis permasalahan yang ada. Tahapan penelitian ini dapat dilihat pada gambar 1 dibawah ini.

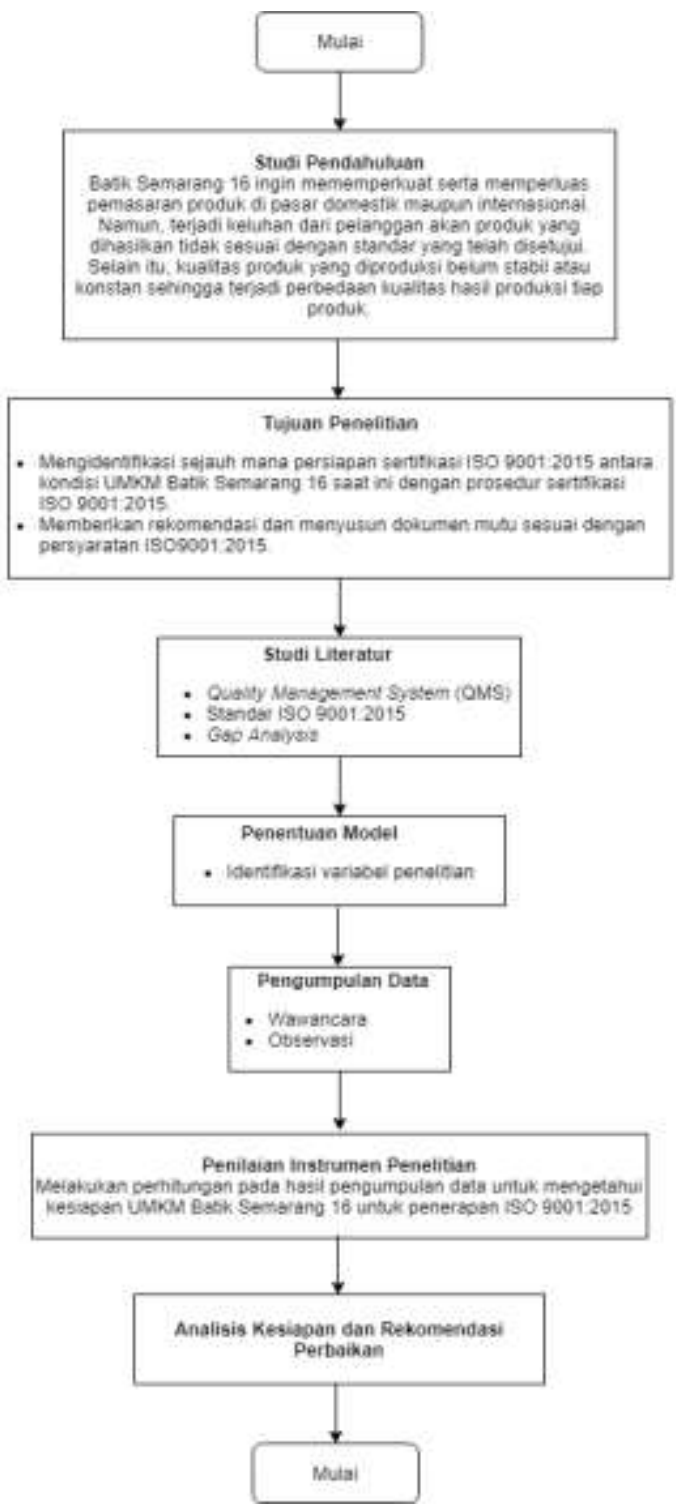

Gambar 1 Alur penelitian

\section{b. Identifikasi Variabel Penelitian}

Variabel penelitian yang digunakan dalam penelitian ini diambil berdasarkan klausul yang terdapat pada ISO 9001:2015. Variabel yang digunakan hanya klausul 4 sampai 10 dimana merupakan persyaratan wajib yang harus dipenuhi perusahaan yang ingin mengimplementasikan ISO 9001:2015. Variabel penelitian dapat dilihat pada tabel 3.

Tabel 3 Variabel penelitian

\begin{tabular}{cc}
\hline No & Klausul \\
\hline 4 & Konteks Organisasi \\
5 & Kepemimpinan \\
6 & Perencanaan \\
7 & Dukungan \\
8 & Operasional \\
9 & Evaluasi Kinerja \\
10 & Peningkatan \\
\hline
\end{tabular}




\section{HASIL DAN PEMBAHASAN}

\section{Pengolahan data}

Pengolahan data dilakukan dengan menghitung rata-rata skor pada variabel yang ada di tabel 4. Hasil perhitungan ini digunakan untuk menilai kesiapan UMKM Batik Semarang 16 dalam sertifikasi ISO 9001:2015. Hasil perhitungan skor pada tiap variabel dapat dilihat pada tabel 4 .

Tabel 4 Rekapitulasi hasil skor checklist

\begin{tabular}{ll}
\hline Klausul & Persentase \\
\hline 4. Konteks organisasi & 74.81 \\
5. Kepemimpinan & 80.82 \\
6. Perencanaan & 82.14 \\
7. Dukungan & 72.08 \\
8. Operasional & 80.38 \\
9. Evaluasi Kinerja & 74.22 \\
10. Peningkatan & 87.50 \\
\hline Rata-Rata & $\mathbf{7 8 . 8 5}$ \\
\hline
\end{tabular}

\section{a. Analisis Hasil Checklist Klausul Konteks Organisasi}

Pada klausul konteks organisasi, diperoleh nilai sebesar $74,81 \%$. Nilai tersebut menandakan bahwa pada klausul ini perlu ada perbaikan. Hasil skor pada klausul konteks organisasi dapat dilihat pada tabel 5.

Tabel 5 Rekapitulasi klausul konteks organisasi

\begin{tabular}{lll}
\hline No & Poin-poin & Nilai \\
\hline 1 & $\begin{array}{l}4.1 \text { Memahami organisasi dan } \\
\text { konteksnya }\end{array}$ & 80 \\
2 & $\begin{array}{l}\text { 4.2 Menentukan ruang lingkup } \\
\text { sistem manajemen mutu }\end{array}$ & 60 \\
3 & $\begin{array}{l}4.3 \text { Sistem manajemen mutu } \\
\text { dan proses-prosesnya }\end{array}$ & 84.44 \\
\hline Nilai Kesiapan & $\mathbf{7 4 . 8 1}$ \\
\hline
\end{tabular}

\section{b. Analisis Hasil Checklist Klausul Kepemimpinan}

Pada klausul kepemimpinan, diperoleh nilai sebesar $80,82 \%$. Nilai tersebut menandakan bahwa pada klausul ini UMKM telah siap melakukan sertifikasi. Hasil skor pada klausul kepemimpinan dapat dilihat pada tabel 6 .

Tabel 6 Rekapitulasi klausul kepemimpinan

\begin{tabular}{lll}
\hline No & Poin-poin & Nilai \\
\hline 1 & $5.1 \quad$ Kepemimpinan dan & 78.46 \\
& komitmen & \\
\hline 2 & $\begin{array}{l}5.2 \text { Kebijakan } \\
3\end{array}$ & $\begin{array}{l}5.3 \text { Peran organisasi, tanggung } \\
\text { jawab, dan otoritas }\end{array}$ \\
\hline Nilai Kesiapan & 84 \\
\hline
\end{tabular}

c. Analisis hasil checklist klausul perencanaan

Pada klausul perencanaan, diperoleh nilai sebesar $82,14 \%$. Nilai tersebut menandakan bahwa pada klausul ini UMKM telah siap melakukan sertifikasi. Hasil skor pada klausul perencanaan dapat dilihat pada tabel 7

Tabel 7 Rekapitulasi klausul perencanaan

\begin{tabular}{llll}
\hline No & Poin-poin & Nilai \\
\hline 1 & $\begin{array}{l}6.1 \text { Tindakan untuk menangani } \\
\text { risiko dan peluang }\end{array}$ & 85 \\
& $\begin{array}{l}6.2 \text { Sasaran mutu dan } \\
\text { perencanaan }\end{array}$ & 81.43 \\
& $\begin{array}{l}\text { mencapainya } \\
3\end{array}$ & 6.3 Perencanaan perubahan & 80 \\
\hline Nilai Kesiapan & $\mathbf{8 2 . 1 4}$ \\
\hline
\end{tabular}

\section{d. Analisis Hasil Checklist Klausul Dukungan}

Pada klausul dukungan, diperoleh nilai sebesar $72,08 \%$. Nilai tersebut menandakan bahwa pada klausul ini perlu ada perbaikan. Hasil skor pada klausul dukungan dapat dilihat pada tabel 8.

Tabel 8 Rekapitulasi klausul dukungan

\begin{tabular}{lll}
\hline No & Poin-poin & Nilai \\
\hline 1 & 7.1 Sumber daya & 80 \\
2 & 7.2 Kompetensi & 75 \\
3 & 7.3 Kesadaran & 50 \\
4 & 7.4 Komunikasi & 80 \\
5 & 7.5 Informasi terdokumentasi & 75,38 \\
\hline Nilai Kesiapan & $\mathbf{7 2 , 0 8}$ \\
\hline
\end{tabular}

\section{e. Analisis Hasil Checklist Klausul} Operasional

Pada klausul operasional, diperoleh nilai sebesar $80,38 \%$. Nilai tersebut menandakan bahwa pada klausul ini UMKM telah siap melakukan sertifikasi. Hasil skor pada klausul operasional dapat dilihat pada tabel 9.

Tabel 9 Rekapitulasi klausul operasional

\begin{tabular}{lll}
\hline No & Poin-poin & Nilai \\
\hline 1 & $\begin{array}{l}8.1 \quad \text { Perencanaan dan } \\
\text { pengendalian operasional }\end{array}$ & 91,11 \\
2 & $\begin{array}{l}\text { 8.2 Persyaratan untuk produk } \\
\text { dan layanan }\end{array}$ & 88,42 \\
\hline 3 & $\begin{array}{l}\text { 8.3 Pengendalian produk dan } \\
\text { layanan eksternal yang } \\
\text { disediakan }\end{array}$ & 49,09 \\
4 & $\begin{array}{l}\text { 8.4 Produksi dan penyediaan } \\
\text { layanan }\end{array}$ & 83,64 \\
5 & $\begin{array}{l}\text { 8.5 Pelepasan atas produk dan } \\
\text { layanan }\end{array}$ & 85 \\
6 & $\begin{array}{l}\text { 8.6 Kendali atas output yang } \\
\text { tidak sesuai }\end{array}$ & 85 \\
\hline Nilai Kesiapan & 80,38 \\
\hline
\end{tabular}




\section{f. Analisis Hasil Checklist Klausul Evaluasi Kinerja}

Pada klausul evaluasi kinerja, diperoleh nilai sebesar $74,22 \%$. Nilai tersebut menandakan bahwa pada klausul ini perlu ada perbaikan. Hasil skor pada klausul evaluasi kinerja dapat dilihat pada tabel 10 .

Tabel 10 Rekapitulasi klausul evaluasi kinerja

\begin{tabular}{lll}
\hline No & Poin-poin & Nilai \\
\hline 1 & 9.1 Pemantauan, pengukuran, & 81,33 \\
2 & analisis, dan evaluasi & \\
3 & 9.2 Audit internal & 62,5 \\
Nilai Kesiapan & 78.82 \\
\hline
\end{tabular}

\section{g. Analisis Hasil Checklist Klausul Peningkatan}

Pada klausul peningkatan, diperoleh nilai sebesar $87,5 \%$. Nilai tersebut menandakan bahwa pada klausul ini UMKM telah siap melakukan sertifikasi. Hasil skor pada klausul peningkatan dapat dilihat pada tabel 11

Tabel 11 Rekapitulasi klausul peningkatan

\begin{tabular}{lll}
\hline No & Poin-poin & Nilai \\
\hline 1 & 10.1 Umum & 95 \\
2 & $\begin{array}{l}10.2 \quad \text { Ketidaksesuaian } \\
\text { tindakan perbaikan }\end{array}$ & dan \\
\hline
\end{tabular}

Nilai Kesiapan 87.5

Rekomendasi Perbaikan

a. Klausul 7 : dukungan, dengan nilai kesiapan sebesar $72,08 \%$

Pada gambar 2 menunjukkan hasil analisis penyebab dasar atau basic event pada klausul dukungan menggunakan metode fault tree analysis yaitu sebagai berikut.

Rekomendasi perbaikan pada klausul dukungan adalah sebagai berikut:

- UMKM membuat jadwal edukasi/training mengenai sistem manajemen mutu secara berkala minimal 1 bulan sekali.

- Menempelkan pamflet atau poster berisi informasi tentang sistem manajemen mutu di area tempat kerja.

- UMKM menentukan, mempersiapkan, dan membentuk tim ISO yang dibutuhkan untuk membangun dan mengimplementasikan SMM yang sesuai dengan ISO 9001:2015.

- Membuat SOP pengendalian dokumen sesuai dengan ISO 9001:2015.

b. Klausul 9 : evaluasi kinerja, dengan nilai kesiapan sebesar $74,22 \%$
Pada gambar 3 menunjukkan hasil analisis penyebab dasar atau basic event pada klausul evaluasi kinerja menggunakan metode fault tree analysis yaitu sebagai berikut.

Rekomendasi perbaikan pada klausul evaluasi kinerja adalah sebagai berikut:

- Melakukan evaluasi performansi SMM bagi setiap manajer dalam kurun waktu satu minggu sekali untuk mengetahui apakah target sudah tercapai.

- Membuat evaluasi kepada penyedia jasa eksternal dengan memasukkan evaluasi tersebut ke dalam dokumen evaluasi dan membuat dokumen kriteria pemilihan pemasok serta menjadikan penyedia jasa eksternal menjadi bagian dari penilaian sistem manajemen mutu perusahaan.

- Membuat dokumen audit internal mengacu pada ISO 9001:2015 sehingga UMKM Batik Semarang 16 dapat memenuhi kriteria audit internal yang dibutuhkan.

- UMKM menentukan, mempersiapkan, dan membentuk tim ISO dan auditor yang dibutuhkan untuk membangun dan mengimplementasikan SMM yang sesuai dengan ISO 9001:2015.

- Membuat dokumen tindakan pebaikan dan pencegahan agar tindakan korektif dari UMKM Batik Semarang 16 lebih efektif.

- Melakukan pengarsipan dokumen evaluasi hasil tinjauan manajemen.

c. Klausul 4 : konteks organisasi, dengan nilai kesiapan sebesar $\mathbf{7 4 , 8 1 \%}$

Pada gambar 4 menunjukkan hasil analisis penyebab dasar atau basic event pada klausul konteks organsiasi menggunakan metode fault tree analysis yaitu sebagai berikut.

Rekomendasi perbaikan pada klausul konteks organisasi adalah sebagai berikut:

- Membuat dokumen ruang lingkup sistem manajemen mutu yang sesuai dengan ISO 9001:2015.

- Membuat rapat rutin membahas isu-isu internal dan eksternal serta strategi perusahaan untuk menyelesaikan permasalahan tersebut.

Rancangan Dokumen Mutu yang Diberikan Rancangan dokumen mutu ini dibuat sesuai dengan persyaratan dokumen wajib yang ada pada klausul ISO 9001:2015 


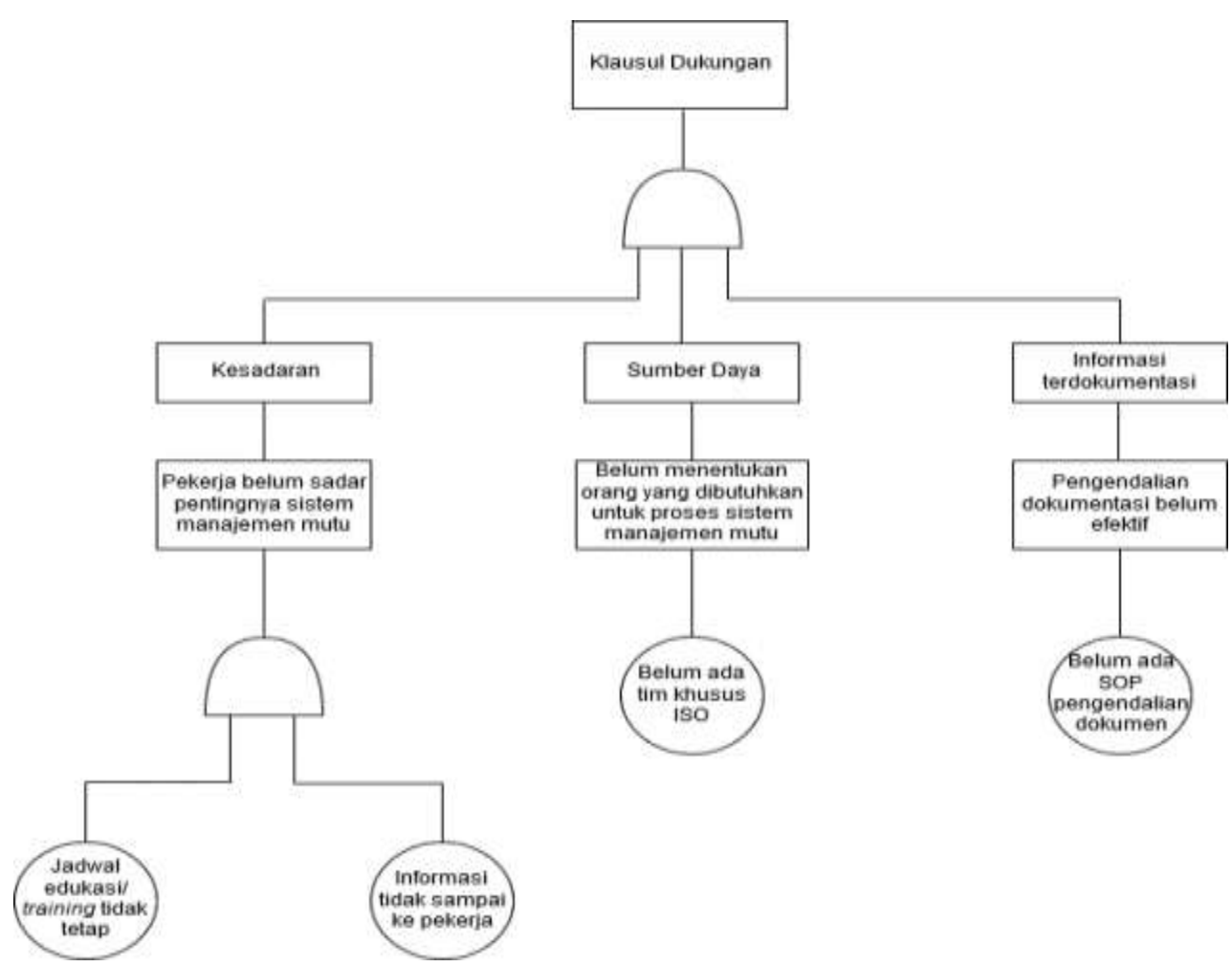

Gambar 2 Fault tree analysis klausul dukungan

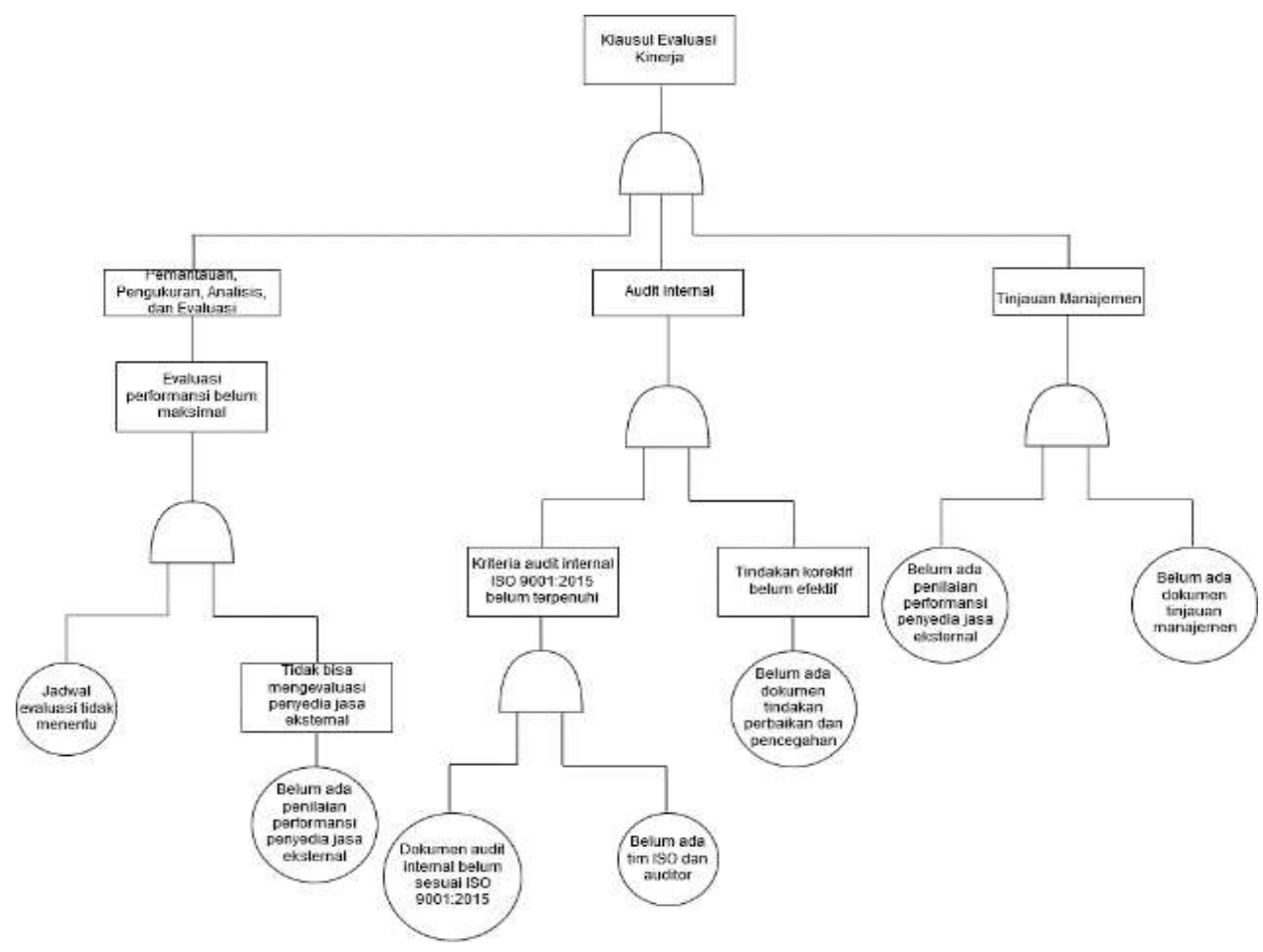

Gambar 3 Fault tree analysis klausul evaluasi kinerja 


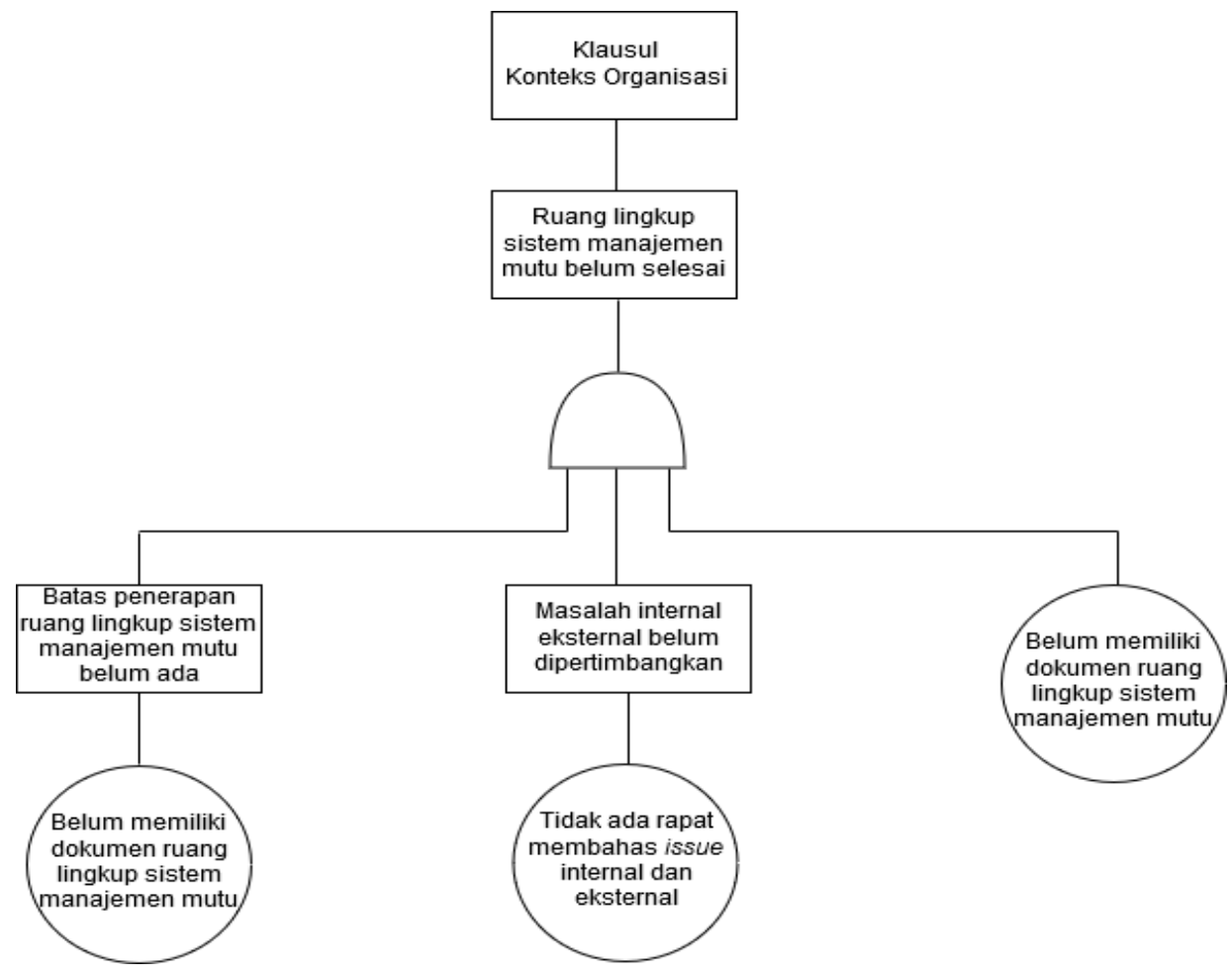

Gambar 4 Fault tree analysis klausul konteks organisasi

Berikut merupakan rancangan dokumen mutu yang dapat dilihat pada Tabel 12.

Tabel 12 Rancangan dokumen mutu

\begin{tabular}{lll}
\hline No & Rancangan Perbaikan & Klausul \\
\hline 1 & Lampiran A1 : Visi Misi & \\
\hline 2 & $\begin{array}{l}\text { Lampiran A2 : Kebijakan } \\
\text { Mutu }\end{array}$ & 5 \\
\hline 3 & Lampiran A3 : Sasaran Mutu & 6 \\
\hline 4 & $\begin{array}{l}\text { Lampiran A4 : Ruang } \\
\text { Lingkup Sistem Manajemen } \\
\text { Mutu }\end{array}$ & 4 \\
\hline 5 & $\begin{array}{l}\text { Lampiran A5 : SOP } \\
\text { Pengendalian Dokumen }\end{array}$ & 7 \\
\hline & $\begin{array}{l}\text { Lampiran A6 : SOP } \\
\text { Pengendalian Rekaman }\end{array}$ & $7,8,9$, \\
\hline 7 & $\begin{array}{l}\text { Lampiran A7 : SOP Audit } \\
\text { Internal }\end{array}$ & 9 \\
\hline 8 & $\begin{array}{l}\text { Lampiran A8 : Tindakan } \\
\text { Perbaikan dan Pencegahan }\end{array}$ & 9,10 \\
\hline 9 & $\begin{array}{l}\text { Lampiran A9: Pengendalian } \\
\text { Ketidaksesuaian }\end{array}$ & 8,10 \\
\hline 10 & $\begin{array}{l}\text { Lampiran A10 : SOP } \\
\text { Tinjauan Manajemen }\end{array}$ & 9 \\
\hline 11 & $\begin{array}{l}\text { Lampiran A11: Kriteria } \\
\text { Pemilihan Supplier }\end{array}$ & 8,9 \\
\hline & \multicolumn{2}{l}{9} \\
\hline 6
\end{tabular}

\section{KESIMPULAN}

Pada penelitian ini, terdapat beberapa kesimpulan yang dapat diambil untuk menjawab tujuan penelitian yaitu sebagai berikut.

1. Berdasarkan hasil analisis gap secara menyeluruh, UMKM Batik Semarang 16 memiliki kesiapan untuk melakukan sertifikasi ISO 9001:2015 sebesar 78,85\%. Hal ini menunjukkan bahwa UMKM Batik Semarang 16 telah siap melakukan sertifikasi ISO 9001:2015. Dilihat dari kesiapan setiap klausul, terdapat tiga klausul yang perlu dilakukan perbaikan, yaitu klausul 7 dengan nilai kesiapan sebesar $72,08 \%$, klausul 9 dengan nilai kesiapan sebesar $74,22 \%$, dan klausul 4 dengan nilai kesiapan sebesar $74,81 \%$.

2. Usulan rekomendasi perbaikan yang diberikan diharapkan dapat meningkatkan hasil dari gap analysis yang dilakukan pada UMKM Batik Semarang 16. Usulan rekomendasi yang diberikan kepada UMKM Batik Semarang 16 dalam bentuk rancangan dokumen mutu, dibuat berdasarkan hasil dari pengolahan data sebagai berikut.

\section{- Klausul 7}

1. Membuat dokumen SOP
Pengendalian Dokumen


2. Membuat dokumen SOP Pengendalian Rekaman

- Klausul 9

1. Membuat dokumen SOP Pengendalian Rekaman.

2. Membuat dokumen SOP Audit Internal

3. Membuat dokumen Tindakan Perbai-kan dan pencegahan

4. Membuat dokumen Tinjauan Manajemen

5. Membuat dokumen Kriteria Pemilihan Pemasok.

- Klausul 4

1. Membuat dokumen Ruang Lingkup Sistem Manajemen Mutu

- Klausul 8

1. Membuat dokumen SOP Pengendalian Rekaman

2. Membuat dokumen Pengendalian Ketidaksesuaian

3. Membuat dokumen Kriteria Pemilihan Supplier

- Klausul 5

1. Membuat dokumen Kebijakan Mutu

- Klausul 6

1. Membuat dokumen Sasaran Mutu

- Klausul 10

1. Membuat dokumen SOP Pengendalian Rekaman

2. Membuat dokumen Tindakan Perbaikan dan Pencegahan

3. Membuat dokumen Pengendalian Ketidaksesuaian

\section{DAFTAR PUSTAKA}

Badan Standardisasi Nasional. (2015). Sistem manajemen mutu. Tidak Diterbitkan.

Boiral, O. (2012). ISO 9000 and Organizational Effectiveness: A Systematic Review. Quality Management Journal, 16-37.
Fernando, J. M., Purwanggono, B., \& Wicaksono, P. A. (2017). Analisis Kesiapan Sertifikasi ISO 9001: 2015 Pada PT. Wijara Nagatsupazki Dengan Menggunakan Metode Gap Analysis. Industrial Engineering Online Journal, 6(2).

Foster, S. (2004). Managing quality : An integrative approach. Prentice-Hall.

Manders, V. B. (2015). ISO 9001 and product innovation: A literature review and research framework. Technovation.

Prakarsa, S. K. (2015). Analisis penerapan sistem manajemen mutu ISO 9001:2008 menggunakan gap analysis tools. Jurnal Rekayasa dan Manajemen Sistem Industri, 3(2015).

Psomas, E. L., Fotopoulos, C. V., \& Kafetzopoulos, D. P. (2010). Critical factors for effective implementation of ISO 9001 in SME service companies. Managing Service Quality: An International Journal, 20(5), 440-457.

Psomas, E., \& Kafetzopoulos, D. (2014). Performance measures of ISO 9001 certified and non-certified manufacturing companies. Benchmarking: International Journal, 21(5), 756-774.

Simanjuntak, M. R. A., \& Suawa, S. S. (2014). Analisis Sistem Manajemen Mutu Dan Pengaruhnya Dalam Meningkatkan Kinerja Operasional Bangunan Gedung Tinggi Perkantoran Di Jakarta Pusat. Jurnal Ilmiah Media Engineering, 4(2).

Tukiran, M. (2016). Membangun Sistem Manajemen Mutu Berdasarkan ISO 9001: 2015. Yogyakarta: LeutikaPrio.

Kementerian Perdagangan RI. Neraca perdagangan indonesia total. (2019). Retrieved from http://www.kemendag.go.id/id/economicprofile/indonesia-export-import/indonesiatrade-balance diakses pada tanggal 21 April 2019 
